\title{
Investigating the Effect of Fundamental Accounting Variables on the Stock Prices Variations
}

\author{
Mahmood Moein Aldin ${ }^{1}$, Hassan Dehghan Dehnavi ${ }^{2}$, Mohammadreza Hajighasemi ${ }^{1} \&$ Ali Hajighasemi $^{3}$ \\ ${ }^{1}$ Department of accounting, Yazd Branch, Islamic Azad University, Yazd, Iran \\ ${ }^{2}$ Department of management, bafgh Branch, Islamic Azad University, bafgh, Iran \\ ${ }^{3}$ Department of management, Yazd Branch, Islamic Azad University, Yazd, Iran \\ Correspondence: Mohammadreza Hajighasemi, Department of accounting, Yazd Branch, Islamic Azad \\ University, Yazd, PO box 89195/155, Shohada-e-Ghomnam Road, Safaiieh, Yazd, Iran. Tel: 98-351-821-1391. \\ E-mail: Hajighasemi.m.r@gmail.com
}

\author{
Received: April 12, $2012 \quad$ Accepted: June 20, $2012 \quad$ Online Published: September 1, 2012 \\ doi:10.5539/ijef.v4n10p125 URL: http://dx.doi.org/10.5539/ijef.v4n10p125
}

\begin{abstract}
Preparing financial statements mainly aims at providing users with the required information in order to help them make economic decisions. Current and potential investors are regarded as information users which are composed of diverse aspects. Investors seek to predict the future stock yields and this can be done through investigating the future stock prices. Hence, predicting future stock price is an essential aspect considered by potential investors. The present paper explores the relationship between changes in fundamental accounting variables with stock price variations of 70 firms listed on Tehran Stock Exchange in a period covering five years from 2006 to 2010 employing Correlation coefficient, adjusted $\mathrm{R}^{2}$ and multiple regressions. The fundamental accounting variables include assets, liabilities, owner's equity, sale, operating income, net income, operating cash flow and investment cash flow. The empirical results reveal that there is a significant relationship between fundamental accounting variables and stock price variations of firms listed on Tehran Stock Exchange. That's why investors should have a special attention to fundamental accounting variables when predicting stock prices and making financial decisions.
\end{abstract}

Keywords: net income, operating income, operating cash flow, liabilities, stock price

\section{Introduction}

Developing capital market is a main composite of economic development and growth. In the last two decades, Iran capital market has also been experiencing a lot of variations such as fluctuations in stock exchanges and increased number of firms listed on the Stock Exchange. The significant role of capital market in economic development caused many researches to be done in Stock Exchanges.

Iran Accounting Standards statement no.1 which considers the financial statements documents that:

"Financial statements aim at providing summarized and classified information about financial position, performance and flexibility for different financial statements users to help them make useful economic decisions."

This statement reflects the comprehensiveness of published financial information which takes into consideration individual investors and creditors. As it can be realized, investors should consider extensive investigations when investing in common stocks. It means that they should have a lot of factors in their mind because they are changing their assets to stocks, otherwise they will make awful decisions which harm their credit. This subject is especially considered in those countries where there are no efficient stock exchanges. There is no need to investigate securities in countries with efficient markets, because market price of stocks is approximately the same as its intrinsic (real) value. It can be concluded that the market value of securities is a suitable proxy for the real value of securities.

Capital market is the place where two major groups interact; investors and investees, among which accounting plays the intermediate role. Investors aim at maximizing their yields and they are very eager to predict the returns of firm's stock in which they invest. A major part of the yields are clarified in stock price increased. The 
present paper seeks to examine the relationship between variations in fundamental accounting variables and the changes in the stock price of firms listed on Tehran Stock Exchange.

\section{Discussion}

\subsection{Literature Review}

$\mathrm{Hu}$ et al. (2008) examined whether sale and income data changes are related to the stock price variations in Taiwan Listed firms. The findings are in consistent with the previous studies in America and Australia stock markets. They found that there is a statistical significant relationship between the variations in sale and income data with stock prices variations. They also revealed that the longer the time duration, the stronger the relation is. Keun et al. (2006) employed the panel data model to investigate the relationship between earnings per share (profit or loss) in Korea stock market. The findings indicate that average stock price variations are affected by earnings per share and other fundamental variables, but this does not verify the consistent level of variations. Chen et al. (2006) examined the accrual items (income and cash flows) and future stock yields and found that firms with high accruals in the period after financial reporting evidenced decreased stock returns.

Hosseini (2006) included automobile and cement industry firms listed on Tehran Stock Exchange and compared the affect of operational income and net cash flows on stock prices. The results showed that investors could not use operational income and net cash flow variables to make decisions about stock exchanges. They also found that this information cannot be used in predicting stock prices. Fouladi (2004) examined the relationship between income statement items variations and changes in stock prices of Tehran Listed firms. The results demonstrated that in more than 54 percent of firms there is a statistical significant relationship between income statement items variations and changes in stock prices. It means that the variations in income statement items might contain useful information for the stock price.

\subsection{Hypothesis Development}

H1- There is a significant relationship between changes in fundamental accounting variables and stock price variations.

H1-1- There is a significant relationship between changes in asset and stock price variations.

H1-2- There is a significant relationship between changes in liabilities and stock price variations.

H1-3- There is a significant relationship between changes in owner's equity and stock price variations.

H1-4- There is a significant relationship between changes in sales and stock price variations.

H1-5- There is a significant relationship between changes in the operating income and stock price variations.

H1-6- There is a significant relationship between changes in Net income and stock price variations.

H1-7- There is a significant relationship between changes in the operating cash flows and stock price variations.

H1-8- There is a significant relationship between changes in the investment cash flows and stock price variations.

\subsection{Methodology}

This paper is classified as an applied research and employs descriptive statistics along with correlation analysis and multi regressions. The amount of each independent variable in a given year is deducted from its amount in the year before, as the first step. Then the figure is divided by the amount of variable in the previous year to calculate the variation percentage of the independent variable. The dependent variable (stock price changes) is achieved through software delivered by Tehran Stock Exchange which shows the average annual stock prices of the firms listed. This amount is deducted from the same amount of the previous year and the result is divided by the average annual stocks prices of the firms. This figure shows the variations percentage in dependent variables. The required data are collected from financial statements publicly published and they were analyzed by employing SPSS software.

\subsubsection{Statistical Population and Research Sample}

We construct our sample starting with all of the companies listed on Tehran stock exchange and collect data for them from 2006 to 2010. Companies in our final sample meet the following criteria:

- The company has data about stock price, along with income statements, balance sheet and cash flow items for at least five years over our 2006-2010 time frames.

- They have been listed on Tehran Stock Exchange before the beginning of 2006 and their stocks should have been exchanged until the end of 2010. 
Finally, there were 299 firms and 70 firms constituted our sample.

\subsection{Hypotheses Testing}

The research hypotheses were tested by employing Pearson correlation coefficient and adjusted $R^{2}(\alpha=0.05)$. The hypotheses are as follows:

H0: There is no significant relationship between fundamental accounting variations (assets, liabilities, owner's equity, sale, operating income, net income, operating cash flows and investing cash flows) and stock price variations of firms listed on Tehran Stock Exchange.

H1: There is a significant relationship between fundamental accounting variations (assets, liabilities, owner's equity, sale, operating income, net income, operating cash flows and investing cash flows) and stock price variations of firms listed on Tehran Stock Exchange.

Table 1 shows the results of correlation tests among independent research variables and stock prices.

According to the table 1, $\mathrm{H} 0$ is rejected and the significant relationship between variables considered is accepted. It can be concluded that there is a relationship between the variations in assets, liabilities, owner's equity, sales, operating income, net income, operating cash flow and the level of stock price variations. The other hypotheses relating to these independent variables are accepted at $99 \%$ level. The results reveal that the independent variables including assets, owner's equity, sales, operating income, net income and operating cash flows are directly correlated with stock prices. That is the inverse and significant relation for the liability. $\mathrm{R}^{2}$ explains the effect of independent variables on the dependent variables. Hence it can be said that $5.9 \%$ of the variations in the stock price are related to the changes in the assets, while $94.1 \%$ are related to the other factors.

Table 1 indicates that the level of significance among the investment cash flows and stock prices changes is equal to 0.827 . It means that investing cash flows variations and stock prices are not correlated.

Table 1. Correlation tests among independent research variables and stock prices

\begin{tabular}{|c|c|c|c|c|c|}
\hline no. & ind .Variable & Pearson Correlation Coefficient & sig. level & $\mathrm{R} 2$ & Hypothesis no. \\
\hline 137 & assets & 0.244 & 0.004 & 0.059536 & 1 \\
\hline 132 & debts & -0.441 & 0.000 & 0.194481 & 2 \\
\hline 137 & owner's equity & 0.383 & 0.000 & 0.145924 & 3 \\
\hline 136 & sale & 0.416 & 0.000 & 0.173056 & 4 \\
\hline 135 & operating income & 0.526 & 0.000 & 0.276676 & 5 \\
\hline 138 & net income & 0.567 & 0.000 & 0.321489 & 6 \\
\hline 135 & operating cash flows & 0.585 & 0.000 & 0.342225 & 7 \\
\hline 135 & investment cash flows & -0.019 & 0.827 & 0.000361 & 8 \\
\hline
\end{tabular}

\subsection{Stock Price Prediction Model}

The correlation coefficient and the level of significance between variables were shown in table 1 . It is evident that in most cases, variables are significantly correlated and this causes no good fitness in the model in which these variables are applied. We have used the stepwise method and added the variables one by one to come into the best fitness. (Table 2)

Table 2. The entered and ommited variables in the model

\begin{tabular}{llll}
\hline Method & Entered Variables & Ommited Variables & Model \\
\hline Stepwise & $\begin{array}{l}\text { operating cash flow } \\
\text { changes }\end{array}$ & 1 \\
operating income & - & 2 \\
Stepwise & $\begin{array}{l}\text { changes } \\
\text { Liability changes }\end{array}$ & - & 3 \\
\hline
\end{tabular}

The variables are characterized as table 3 : 
Table 3. variables coding

\begin{tabular}{llllll}
\hline variable name & Name & variable name & name & variable name & name \\
\hline stock price changes & $\mathrm{Y}$ & owner's equity changes & $\mathrm{X}_{3}$ & net income changes & $\mathrm{X}_{6}$ \\
asset changes & $\mathrm{X}_{1}$ & sale changes & $\mathrm{X}_{4}$ & operating cash flows changes & $\mathrm{X}_{7}$ \\
& & & & \\
liability changes & $\mathrm{X}_{2}$ & operating income changes & $\mathrm{X}_{5}$ & investment cash flows changes & $\mathrm{X}_{8}$ \\
& & & & & \\
\hline
\end{tabular}

Operating cash flow changes are the most correlated with the stock price variations, so they are entered as the first variable, this is followed by entering the operating income changes in the second model and the liability changes in the third one. There is no omitted variable in the models.

The suggested models are represented as follows ( table 4 ):

Model $1 \quad \mathrm{Y}=\alpha+\beta_{7} \mathrm{X}_{7}+\varepsilon$

Model $2 \quad \mathrm{Y} Y=\alpha+\beta_{7} \mathrm{X}_{7}+\beta_{5} \mathrm{X}_{5}+\varepsilon$

Model $3 \quad Y=\alpha+\beta_{7} X_{7}+\beta_{5} X_{5}+\beta_{2} X_{2}+\varepsilon$

Table 4. Summarize of the Models

\begin{tabular}{lllll}
\hline Error & on Coefficient & R2 & adjusted R2 & Model \\
\hline 2955.6 & 0.569 & 0.324 & 0.319 & 1 \\
2768.5 & 0.642 & 0.412 & 0.403 & 2 \\
2641.2 & 0.684 & 0.468 & 0.456 & 3 \\
\hline
\end{tabular}

Table 4 represents that the highest $\mathrm{R}^{2}$ belongs to the third model and that is why this model have been chosen. Nearly $45.6 \%$ of the variations in the dependent variables (stock price changes) depend on the factors noted in the model 3 (operating cash flow variations, investing cash flow changes and liability changes). In the other words, those factors can predict less than $50 \%$ of the variations in the stock price, while the rest of changes are because of the other factors. Statistically, when the regression fitness model is significant, then the regression results are considered reliable. We employed analysis of variance to examine the significance of the multiple regressions. Finally, H0 was defined and tested using ANOVA. ( table 5 )

$\mathrm{H} 0$ : regression model is not significant.

H1: regression is significant.

The significance level of all the models are 0.00 and this causes $\mathrm{H} 0$ to be rejected at 99 percent

Table 5. Summarized ANOVA

\begin{tabular}{lllllll}
\hline Model & & Sum of Squares & Degree of Freedom & Mean of the Squares & F-statistics & Significant Level \\
\hline \multirow{3}{*}{1} & regression & 557483506.567 & 1 & 557483507 & 63.816 & 0.000 \\
& residual & 1161867527.600 & 133 & 8735846.07 & & \\
& total & 1719351034.167 & 134 & & & \\
& regression & 707605177.343 & 2 & 353802589 & 46.16 & 0.000 \\
2 & residual & 1011745856.800 & 132 & 7664741.34 & & \\
& total & 1719351034.143 & 134 & & 38.49 & 0.000 \\
& regression & 805509544.441 & 3 & 268503181 & & \\
& residual & 913841489.720 & 131 & 6975889.23 & & \\
& total & 1719351034.161 & 134 & & & \\
\end{tabular}


In the other words, all the regression models are significant.( table 6 )

Table 6. Regression results

\begin{tabular}{|c|c|c|c|c|c|c|}
\hline \multirow{2}{*}{ Model } & & \multicolumn{2}{|c|}{ non-standardized values } & \multirow{2}{*}{$\begin{array}{l}\text { coefficient } \\
\beta \\
\end{array}$} & \multirow{2}{*}{$\mathrm{T}$} & \multirow{2}{*}{ significance level } \\
\hline & & $\beta$ & error & & & \\
\hline \multirow{2}{*}{1} & constant value & 752.639 & 259.617 & & 2.899 & 0.004 \\
\hline & operating cash flows variations & 0.033 & 0.004 & 0.569 & 7.988 & 0.000 \\
\hline \multirow{3}{*}{2} & constant value & 652.662 & 244.228 & & 2.672 & 0.008 \\
\hline & operating cash flows variations & 0.024 & 0.004 & 0.418 & 5.57 & 0.000 \\
\hline & operational income changes & 0.011 & 0.002 & 0.332 & 4.426 & 0.000 \\
\hline \multirow{4}{*}{3} & constant value & 813.733 & 236.929 & & 3.435 & 0.001 \\
\hline & operating cash flows variations & 0.022 & 0.004 & 0.376 & 5.191 & 0.000 \\
\hline & operational income changes & $0 / 010$ & 0.002 & 0.313 & 4.362 & 0.000 \\
\hline & liability variations & -0.005 & 0.001 & -0.245 & -3.746 & 0.000 \\
\hline
\end{tabular}

The table 6 represents the regression results in three models. As it is obvious, $\mathrm{R}^{2}$ in the third model owned the highest value and caused this model to be chosen. The equation related to the model is explained as follows:

$$
\varepsilon+X_{2}-0 / 005 X_{5}+0 / 010 X_{7}=813 / 733+0 / 022 Y
$$

The defined regression equation is illustrated:

- $\quad$ Constant value of the model is 813.733 .

$022 / 0 \mathrm{X}_{7}$ reflects the 0.022 increase in stock price resulting from one unit increase in operating cash flows.

- $\quad 010 / 0 \mathrm{X}_{5}$ reflects the 0.010 increase in stock price resulting from one unit increase in the operating income.

- $005 / 0 \mathrm{X}_{2}$ reflects the 0.005 decrease in the stock price resulting from one unit increase in liabilities.

\section{Conclusions}

Based on the hypotheses tested through the study, we have found that there is a significant relationship among assets, liabilities, owner's equity, sales, net income, operating income and operating cash flows variations and stock price changes. But this does not hold true for the relationship between investing cash flows variations and stock price changes. Accordingly, it can be concluded that changes in the financial statements items are correlated with the stock price changes of the firms listed on Tehran Stock Exchange. The results document that investors ought to take into account the financial statements when predicting stock prices and economic decision makings.

\section{Suggestions}

The results of this study suggest that financial statements users including current and potential investors and creditors should pay special attention to the variations in the asset, liability and owner's equity from balance sheet; sale, operating income and net income from income statement; and operating cash flow from cash flow statements to achieve the highest yields. Investors are also suggested to employ the third regression model which can predict $45.6 \%$ of variations in the stock price. Since more than half of the variations in stock price variations are explained by the changes in the financial statement items, then users should consider external and non-financial factors in the field of economic decision making and stock price prediction.

\section{References}

Chan, K.C., Chan, L., Jegadees, N. J., \& Lakanishok. (2006). Earning Quality and Stock Return, Journal of business, for the cominy, 48, 321-340. http://ideas.repec.org/a/ucp/jnlbus/v79y2006i3p1041-1082.html

Fouladi, M. (2004). The Analysis of the Relationship between the Changes in the Items of Income Statement and Stock Price Variations in Firms Listed on Tehran Stock Exchange. M.A Thesis, Tehran, NY: Tarbiat Modaras University.

Hosseini, J. (2006). The comparative Investigation of Operating Income Impact and Net Cash Flow on Stock Prices of Firms Listed On Tehran Stock Exchange, M.A Thesis, Tehran, NY: Islamic Azad University. http://tuasr.blogfa.com/post-59.aspx

How, In-mu, Qi, Doqing, \& Wu, Woody. (2001). The nature of information in accruals and cash flows in an earning capital market: The case of China. The International Journal of Accounting, 20(4), 391-406. 
http://ideas.repec.org/a/eee/accoun/v36y2001i4p391-406.html

Jahankhani, A., \& Moradi, M. (1997). Investigating the Decision Making Behavior of Common Stock Buyers in Tehran Stock Exchange, the first conference on financial management in Iran, Administrating Sciences, Tehran, NY: Shahid Beheshti University. http://www.ensani.ir/storage/Files/20101207190136-36778.pdf

Keun-Yeob Oh, Bonghan K., \& Honkee. ( 2006). An Empirical Study of the Relation Between Stock Price and EPS in Panel Data: Korea Case, Applied Economics, 38, 2361-2369. http://www.tandfonline.com/doi/abs/10.1080/00036840500427593\#preview

Noferesti, M. (2001). Statistics in Economics and Commerce ( $2^{\text {nd }}$ ed), Tehran, NY: Rasa Institute of cultural services.

Oh Hu, Zhoadan Huang, \& Bih-shuang Liao. (2009). Short sale and stock returns: Evidence from the Taiwan Stock Exchange. The Quarterly Review of Economics and finance, 49(3), 1146-1158. http://econpapers.repec.org/article/eeequaeco/v_3a49_3ay_3a2009_3ai_3a3_3ap_3a1146-1158.htm 